\title{
Diffusional nutrient fluxes at the sediment-water interface and organic matter mineralization in an atoll lagoon (Tikehau, Tuamotu Archipelago, French Polynesia)
}

\author{
Claude Charpy-Roubaud ${ }^{1, * * *}$, Loïc Charpy ${ }^{1, *}$, Gérard Sarazin ${ }^{2}$ \\ ${ }^{1}$ Centre ORSTOM de Tahiti, BP 529, Papeete, Tahiti, French Polynesia \\ ${ }^{2}$ Université Paris 7, Laboratoire de Géochimie des Eaux, F-75251 Paris Cedex 05, France
}

\begin{abstract}
Fluxes of dissolved inorganic N, P and Si from the sediments were calculated using pore water gradient concentration measured using the peeper technique at 8 stations in the lagoon of Tikehau Atoll, French Polynesia. Nutrient concentrations of pore water reached maximum values of $130 \mu \mathrm{M}$ $\mathrm{NH}_{4}, 7 \mu \mathrm{M} \mathrm{PO}_{4}$ and $30 \mu \mathrm{M} \mathrm{SiO}$. Fluxes calculated from concentration gradients were positive at all stations. $\mathrm{N}$ and $\mathrm{P}$ fluxes represented 6 and $4 \%$ of the $\mathrm{N}$ and $\mathrm{P}$ deposition rates and between 0.1 and $6.8 \%$ of the $\mathrm{N}$ requirements and between 0.1 and $1.7 \%$ of the P requirements of lagoonal primary production. Study of geochemical processes and stoichiometry of the organic matter shows that a great part of deposited organic matter is oxidized in the water colunn. The amount of organic matter oxidized inside the sediment is estimated to $2.5 \mathrm{mg} \mathrm{kg}^{-1}$ in the upper centimeter and $5.2 \mathrm{mg} \mathrm{kg}^{-1}$ below. Pore water was supersaturated with respect to aragonite and calcite, and the kinetics of carbonate dissolution were faster than the reverse reaction. The dissolution/precipitation of carbonate plays an important role in the composition of the pore water
\end{abstract}

KEY WORDS: Nutrient fluxes · Sediment $\cdot$ Pore water $\cdot$ Peeper $\cdot$ Atoll lagoon $\cdot$ Mineralisation

\section{INTRODUCTION}

Nutrient fluxes on coral reef environments have been extensively studied (see reviews of Lewis 1977, Crossland 1983, Kinsey 1985, Atkinson 1989, Boucher \& Clavier 1990, Hatcher 1990, Capone et al. 1992). At the level of the whole reef ecosystem (reef flat + lagoon), net community productivity appears to be but a tiny fraction of the gross production rate, implying that reef ecosystems accumulate biomass slowly and export little of it (Hatcher 1990). Atkinson (1989) asked the question: 'Is the rate of nutrient supply greater than the rate of nutrient uptake?'. The answer is more accessible in ecosystems with high water residence

\footnotetext{
- Present address: ORSTOM, COM, Rue de la Batterie des Lions, F-13007 Marseille, France

-E-mail: clcharpy@orstom.orstom.fr
}

times: weeks, months or years. For example, the lagoon of Tikehau Atoll, French Polynesia, has an average water residence time estimated at $176 \mathrm{~d}$ (Lenhardt 1991). Its phosphorus budget is largely balanced by phosphate input from oceanic waters (Charpy-Roubaud et al. 1990). If we compare the phosphate input (from oceanic waters) per $\mathrm{m}^{2}$ of lagoon, $60 \mu \mathrm{mol} \mathrm{m}{ }^{-2} \mathrm{~d}^{-1}$ (calculated from Charpy-Roubaud et al. 1990), to the phosphate uptake by the phytoplankton + phytobenthos, $600 \mu \mathrm{mol} \mathrm{m}{ }^{-2} \mathrm{~d}^{-1}$ (calculated from Charpy \& Charpy-Roubaud 1989), it is apparent that $90 \%$ of the lagoonal phosphate requirements must be supplied by remineralization and recycling processes.

Nutrient mineralization may occur in the water column (excretion and bacterial metabolism), at the sediment-water interface (SWI) or within the sediments. The importance of the recycling of autochthonous material at the SWI and within the sediments can be estimated by measuring nutrient fluxes at the SWI 
We calculated these fluxes based on measurements of chemical gradients close to the SWI. This approach requires pore water analysis and has been used by many authors since the pioneer work of Hesslein (1976), e.g. Devol \& Ahmed (1981), Gaillard et al. (1989)

In this paper we estimate nutrient fluxes at the SWI to compare Tikehau's fluxes with fluxes in other coral reef lagoons and with the deposition of organic matter and nutrient requirements of primary production in Tikehau lagoon (data in Charpy \& Charpy-Roubaud 1991 and Charpy-Roubaud et al. 1989).

\section{MATERIAL AND METHODS}

Location of experimental sites. The main geographical and geomorphological features of Tikehau Atoll are described in Harmelin-Vivien (1985). Three stations were surveyed in 1987 (1,4 and 8) and 6 in 1993 $(2,3,5,6,7$ and 8 ) (Fig. 1). Stn 1 was located close to the interior reef flat. Stns 2 and 3 were chosen because of their leeward and windward locations (with respect to the prevailing wind direction) relative to a pinnacle. Stns 4, 5 and 6 exhibited depths similar to the average depth of the lagoon $(25 \mathrm{~m})$, while Stns 7 and 8 were located in the deepest part of the lagoon.

Sediment cores from these stations exhibited a general similarity in appearance: all were of fine- to very

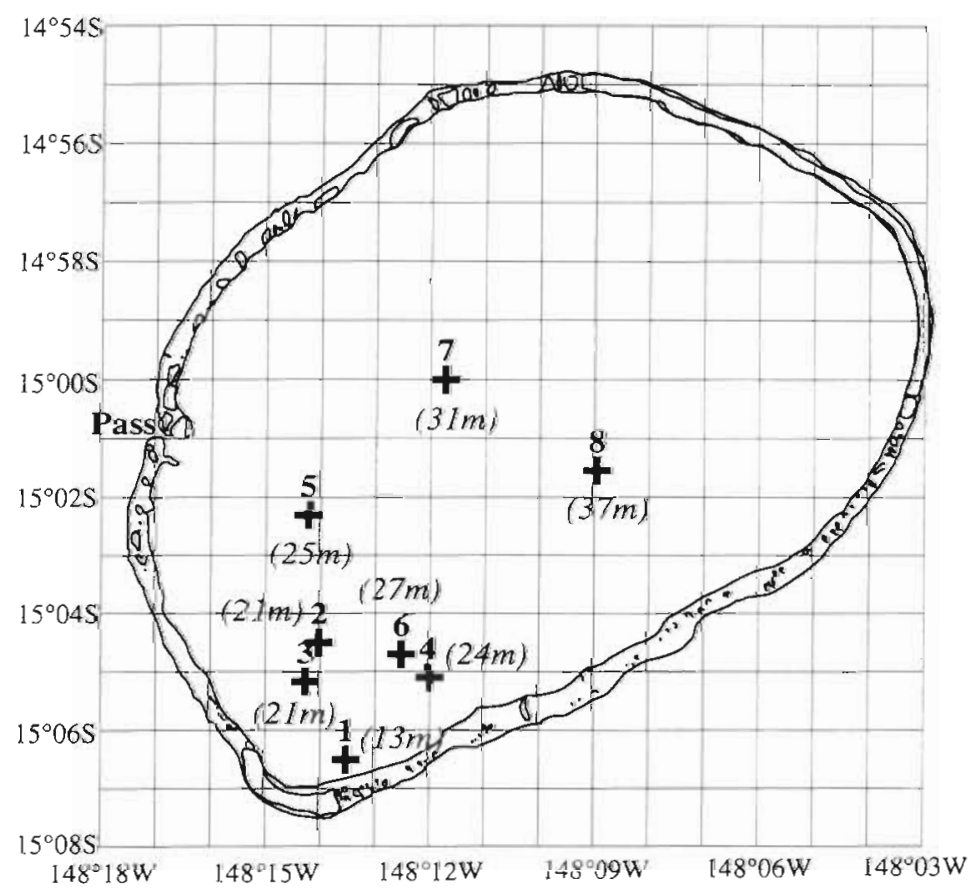

Fig. 1. Location of sampling stations, Tikehau Atoll, French Polynesia fine-grained coral sand $(<400 \mu \mathrm{m})$ as was observed in the other parts of the lagoon (Intes \& Arnaudin 1987). At all stations, the superficial sediment showed spectacular marks of bioturbation (cones and burrows), mainly due to Callianacea (Crustacean). Sea grass mats of Halophila ovata were commonly observed. The sand community was mainly composed of diatoms, cyanobacteria and foraminifera embedded in coral debris

Pore water sampling and anailytical methods. We used the in situ peeper sampling method described by Hesselein (1976). The peepers were inserted in the sediment and left on the site for at least $15 \mathrm{~d}$ in order to equilibrate the initial pore water with the interstitial medium. According to the size of the peeper chambers ( 3 or $10 \mathrm{ml}$ ), the spatial resolution was either $1 \mathrm{~cm}$ or $2.5 \mathrm{~cm}$. These chambers were covered with a Biodyne A membrane (pore size $0.2 \mu \mathrm{m}$ ).

In the field. The pore water was collected from the chambers with disposable syringes which were quickly punched in a rubber stopper to prevent any exchange with the atmosphere. An aliquot for sulfide analysis was transferred into a blood-collecting vacuum tube which contained $1 \mathrm{ml}$ of a solution prepared by dissolving $0.2 \mathrm{~g}$ $\mathrm{ZnCl}_{2}$ and $2 \mathrm{~g}$ gelatin $\mathrm{l}^{-1}$. This procedure prevents $\mathrm{H}_{2} \mathrm{~S}$ outgassing and further oxidation by converting the initial soluble sulfide species into an homogeneous suspension of $\mathrm{ZnS}$. Aliquots to be used in Ca analysis were acidified with $100 \mu l$ of ultrapure concentrated hydrochloric acid $(10 \mathrm{M})$ while $100 \mu l$ of ultrapure cadmium acetate solution ( $1 \mathrm{M}$ ) was added to subsamples to be used in $\mathrm{SO}_{4}$ analysis in order to prevent reoxidation of sulfide into sulfate. All the samples were kept in an icebox $\left(0^{\circ} \mathrm{C}\right)$ on the way back to the laboratory.

In the laboratory. The $\mathrm{pH}$ was determined at room temperature $\left(22^{\circ} \mathrm{C}\right)$ on submicrosamples $(500 \mu l)$ using an Ingold micro-electrode and the Hansson's calibration method described by Almgren et al. (1975) with a precision of $\pm 0.01 \mathrm{pH}$ unit. Gran's potentiometric titration was used for alkalinity measurements (Stumm \& Morgan 1981). The accuracy was $\pm 0.5 \%$. Standard colorimetric procedures, adapted for submicrosamples (Merck Spectroquant methods; sample volume 0.5 or $1 \mathrm{ml}$, precision $\pm 4 \%)$ were used for nutrient analysis $\left(\mathrm{SiO}_{2}\right.$, $\mathrm{NH}_{4}$ and $\mathrm{PO}_{4}$ ) and total dissolved sulfide.

A known volume of the $\mathrm{ZnS}$ suspension was used in colorimetric analysis of $\mathrm{H}_{2} \mathrm{~S}$ using the conventional methylene-blue method with a precision of $3 \%$. The first step of the colorimetric analysis was a strong acidification of the standard or sample solution, which completely dissolved the ZnS suspension. Ca was ana- 
lyzed by conventional AAS procedures with a precision of $\pm 5 \%$.

Flux calculation. Rates of efflux of N,P and Si from the sediments were calculated using the equations of Rutgers van der Loeff et al. (1984) (Fick's first law of diffusion):

$$
F=\phi D_{S} \frac{\mathrm{d} C}{\mathrm{~d} z}
$$

where $F$ is the rate of efflux $\left(\mu \mathrm{mol} \mathrm{m} \mathrm{m}^{-2} \mathrm{~d}^{-1}\right), \phi$ is sediment porosity (dimensionless), $D_{S}$ is the effective diffusion coefficient (in $\mathrm{m}^{-2} \mathrm{~d}^{-1}$ ), and $\mathrm{d} C / \mathrm{d} z$ is the concen-

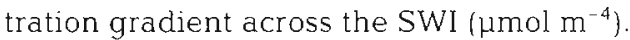

The measured porosity $(\phi)$ of coral sand sediment was the same from one station to another: $0.63 \pm 0.01$. The apparent diffusion coefficients in deionized water $\left(D_{0}\right)$, taken from Manheim (1970) and Li \& Gregory (1974) for a water temperature of $25^{\circ} \mathrm{C}$, were corrected for tortuosity using a porosity of 0.63 and porosity-tortuosity relationships reported by Sweerts et al. (1991). The apparent diffusion coefficients for the flux across the SWI $\left(D_{S}\right)$ thus calculated for $\mathrm{NH}_{4}, \mathrm{PO}_{4}$ and Si were respectively $9.85,3.72$ and $5.01 \mathrm{~m}^{2} \mathrm{~d}^{-1}$

Since the evaluations of $D_{S}, \phi$ and $\mathrm{d} C / \mathrm{d} z$ are independent, the cumulative error on the flux calculation can be estimated at $\pm 40 \%$.
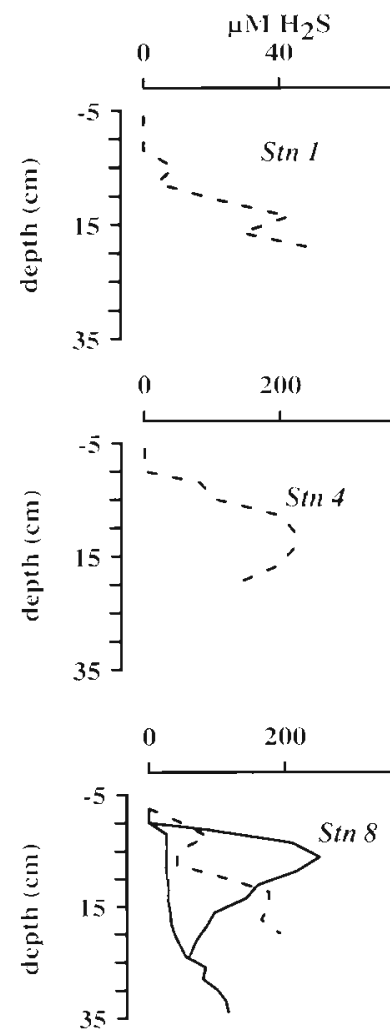
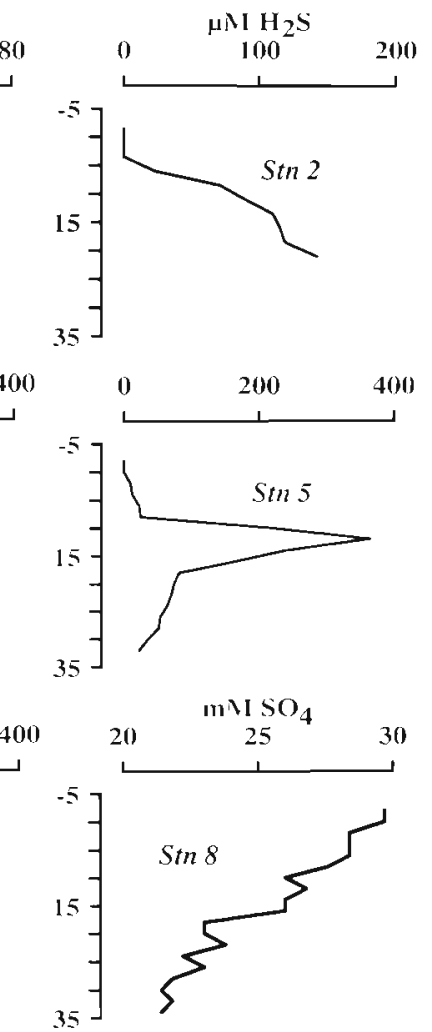

Fig. 2. Pore water profiles of $\mathrm{H}_{2} \mathrm{~S}(\mu \mathrm{M}$; Stns $1,2,4,5,8)$ and $\mathrm{SO}_{4}(\mathrm{mM} ; \mathrm{Stn} 8$ ) concentrations. Dashed lines are 1987 data solid lines are 1993 data. No data for Stns 3,6 and 7

\section{RESULTS}

\section{Nutrient concentration profiles}

The pore water nutrient profiles showed significant concentration gradients with depth. These gradients were at a maximum within the upper few centimeters. $\mathrm{H}_{2} \mathrm{~S}$ (Fig. 2) appeared at a few $\mathrm{mm}$ and at $2 \mathrm{~cm}$ below the SWI at Stns 5 and 8 , while this redox limit was located between 3 and $5 \mathrm{~cm}$ below the SWI at Stns 1, 2 and $4 . \mathrm{An} \mathrm{SO}_{4}$ concentration profile was available only at Stn 8 (Fig. 2). The $\mathrm{PO}_{4}$ profiles (Fig. 3) exhibited 2 major patterns: an increasing concentration from the interface, with maxima ranging from 2 to $6 \mu \mathrm{M}$, between 4 and $6 \mathrm{~cm}$ below the surface (Stns 2, 3,6 and 8), and an increasing concentration, with maxima ranging from 2 to $5 \mu \mathrm{M}$, between 10 and $25 \mathrm{~cm}$ below the surface (Stns 1, 4, 5 and 7). The dissolved silica profiles
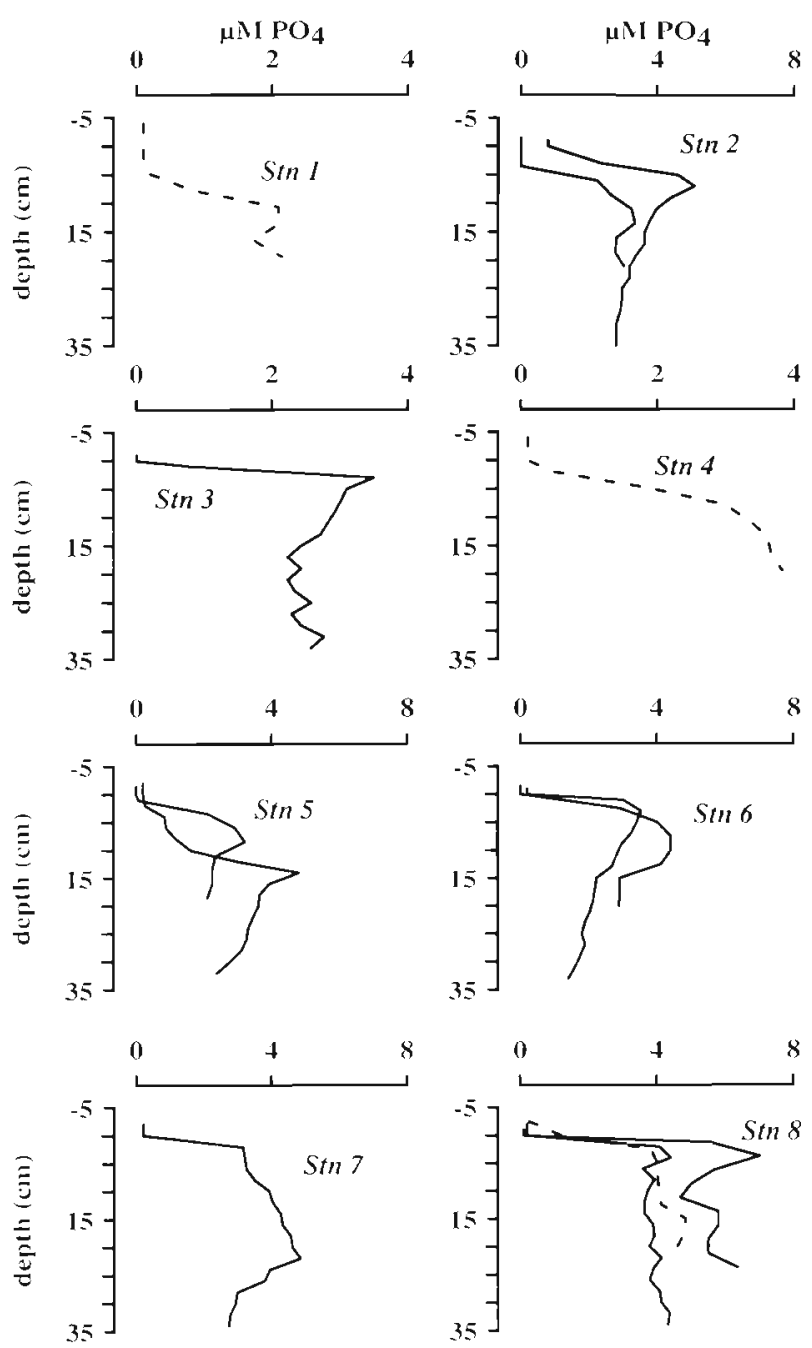

Fig. 3. Pore water profiles of $\mathrm{PO}_{4}$ concentrations ( $\mathrm{MM}$ ). Dashed lines are 1987 data, solid lines are 1993 data 

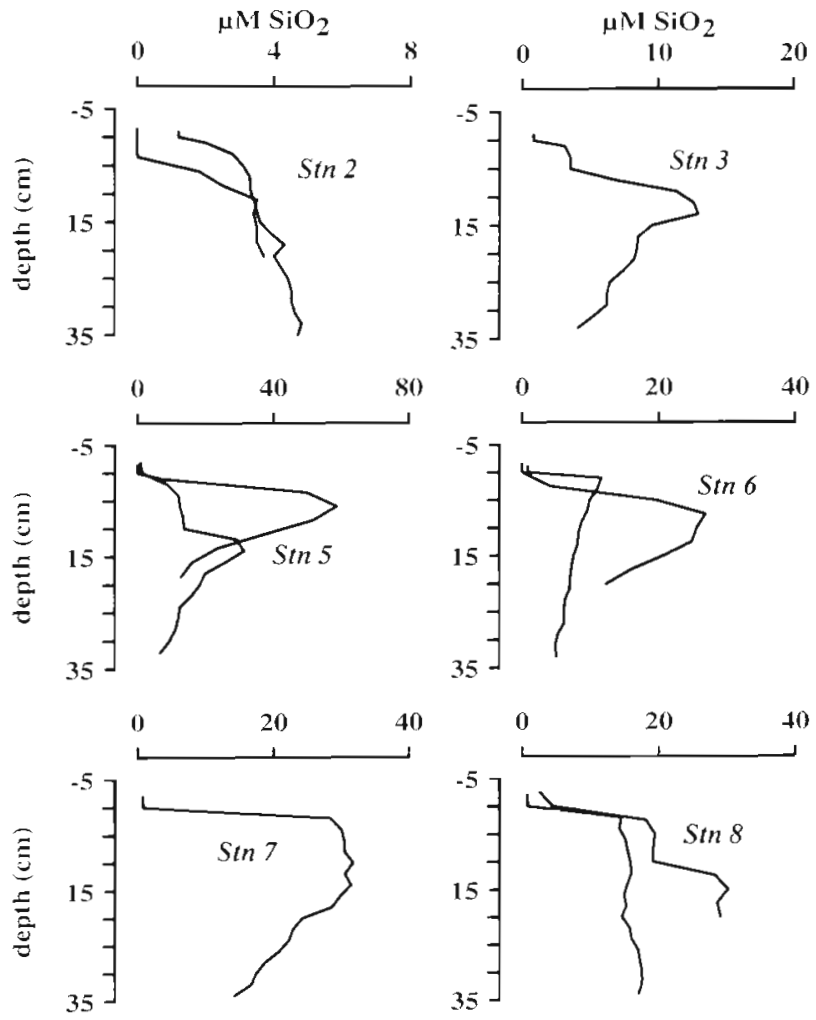

Fig. 4. Pore water profiles of $\mathrm{SiO}_{2}$ concentrations $(\mu \mathrm{M})$ from 1993 data. No data for Stns 1 and 4

(Fig. 4) also exhibited 2 major patterns: a regular but minor increase of concentration with depth along the sediment core (Stns 2 and 8), and an increasing concentration going through a maximum followed by a regular decrease (Stns 3, 5, 6 and 7), the highest concentrations being observed at Stns $5(59 \mu \mathrm{M})$ and 7 (32 $\mu \mathrm{M})$. Ammonium profiles (Fig. 5) show either a regular increase as observed at Stns 1, 2 and 6 or a mid-depth maximum concentrations as seen at Stns 5 (102 and $180 \mu \mathrm{M}$ ) and 7 (101 $\mu \mathrm{M}$ ).

\section{Nutrient fluxes}

Calculated $\mathrm{NH}_{4}$ fluxes ranged from 4.2 at $\operatorname{Stn} 3$ to $600.7 \mu \mathrm{mol} \mathrm{m} \mathrm{m}^{-2} \mathrm{~d}^{-1}$ at $\operatorname{Stn} 8$, those of $\mathrm{PO}_{4}$ from 0.6 at Stn 3 to $10.3 \mu \mathrm{mol} \mathrm{m}{ }^{-2} \mathrm{~d}^{-1}$ at Stn 6 and those of Si from 2.7 at $\operatorname{Stn} 2$ to $79.2 \mu \mathrm{mol} \mathrm{m} \mathrm{m}^{-2} \mathrm{~d}^{-1}$ at Stn 7 (Table 1). Integrated $\mathrm{PO}_{4}$ and $\mathrm{NH}_{4}$ concentrations, calculated by a trapezoidal integration of nutrient profiles in the upper $20 \mathrm{~cm}$ of sediments, were correlated with station depth $(r=0.79, n=13$ and $r=0.73, n=11)$ (Fig. 6). The rate of sedimentation of organic matter from the overlying water column was certainly one factor in the influence of depth on pore water nutrient concentrations. Accordingly, calculated fluxes of $\mathrm{NH}_{4}$ and $\mathrm{PO}_{4}$ were also correlated with depth $(r=0.73$ and $r=0.73)$.
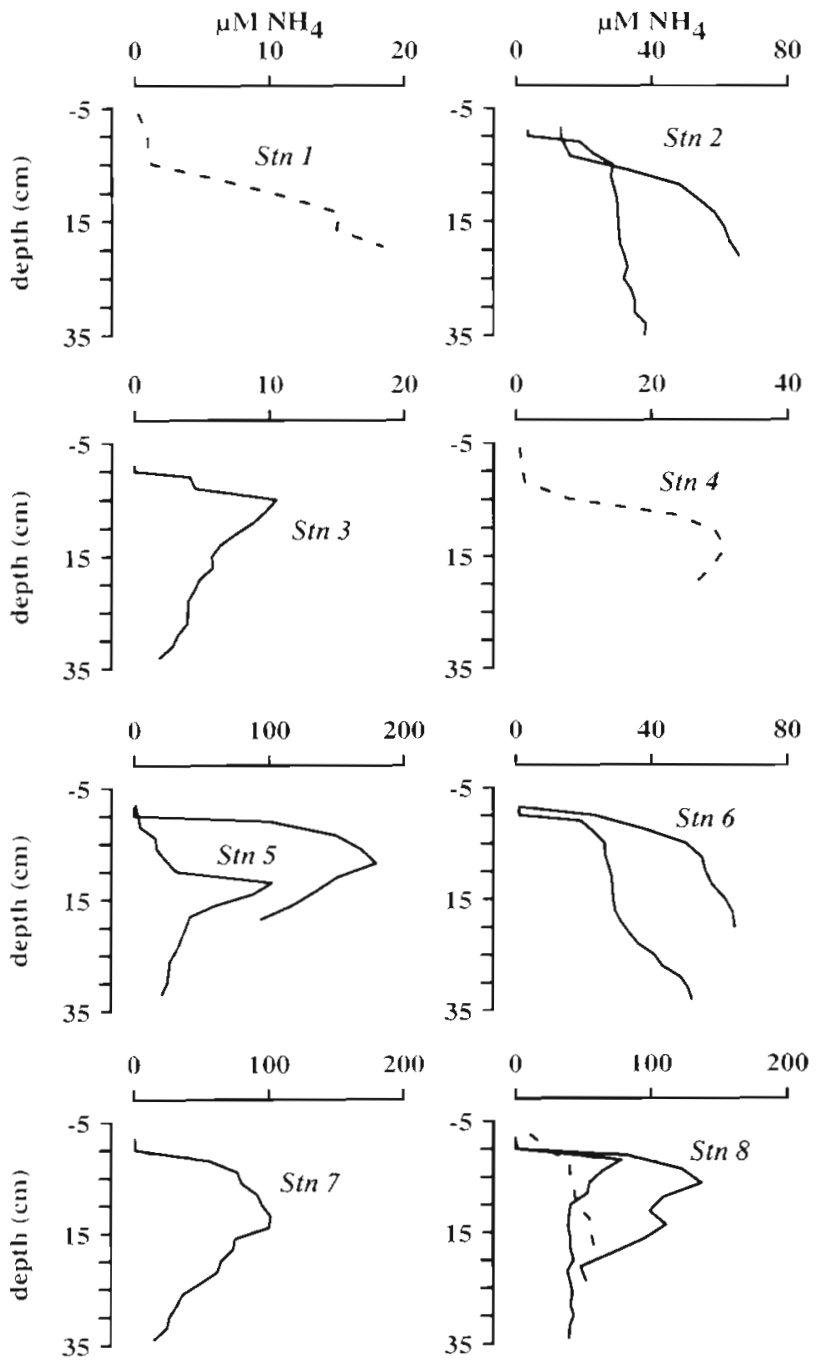

Fig. 5. Pore water profiles of $\mathrm{NH}_{4}$ concentrations ( $\mathrm{MM}$ ). Dashed lines are 1987 data, solid lines are 1993 data

Table 1 Nutrient fluxes ( $\mu \mathrm{mol} \mathrm{m}^{-2} \mathrm{~d}^{-1}$ ) calculated using pore water concentration gradients and N:P atomic ratio of efflux. nd: not determined

\begin{tabular}{|lrrrrr|}
\hline Stn & Depth & $\mathrm{NH}_{4}$ & $\mathrm{PO}_{4}$ & $\mathrm{~N}: \mathrm{P}$ & $\mathrm{Si}$ \\
\hline May 1987 & & & & & \\
1 & 13 & 10.0 & 0.8 & 13.1 & nd \\
8 & 36 & 188.6 & 6.0 & 31.6 & nd \\
4 & 24 & 18.3 & 0.9 & 20.1 & nd \\
April 1993 & & & & & \\
3 & 21 & 4.2 & 0.6 & 25.1 & 14.8 \\
2 & 21 & 78.8 & 3.0 & 25.9 & 2.7 \\
8 & 36 & 600.7 & 8.9 & 67.6 & 53.4 \\
6 & 27 & 133.4 & 10.3 & 13.0 & 34.1 \\
5 & 25 & nd & 2.3 & nd & 57.8 \\
7 & 31 & 273 & 7.7 & 35.4 & 79.2 \\
\hline
\end{tabular}




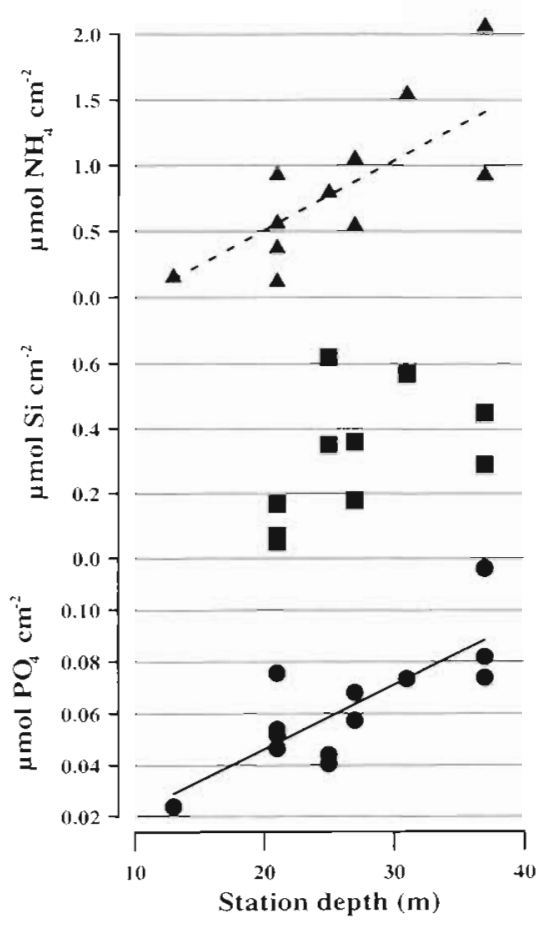

Fig. 6. Integrated nutrient concentrations (upper $20 \mathrm{~cm}$ ) versus station depth; lines are linear fits

\section{pH, alkalinity and calcium profiles}

For all the stations we observed the following general trends: $\mathrm{pH}$ started to decrease immediately below the interface, i.e. $1 \mathrm{~cm}$ below the sediment surface (Fig. 7). The calcium profile, which was available only at $\operatorname{Stn} 8$, exhibited a constant concentration close to $12.5 \mathrm{mM}$ (Fig. 8). Alkalinity maxima were observed between 5 and $15 \mathrm{~cm}$ at Stns 3, 5, 6 and 8 (1987 data) and between 0 and $5 \mathrm{~cm}$ at Stns 2 and 8 (1993 data) (Fig. 8).

\section{DISCUSSION}

\section{Comparison with other coral reef sediments}

Tikehau $\mathrm{PO}_{4}$ and $\mathrm{NH}_{4}$ flux ranges $(0.9$ to $12.0 \mu \mathrm{mol}$ $\mathrm{PO}_{4} \mathrm{~m}^{-2} \mathrm{~d}^{-1}$ and 4.4 to $387.0 \mu \mathrm{mol} \mathrm{NH}_{4} \mathrm{~m}^{-2} \mathrm{~d}^{-1}$ ) were very large and are comparable to the diffusional flux ranges reported for other coral reef areas (Table 2). In comparison, in eutrophic areas such Orbetello lagoon (Grosseto, Italy), diffusional nutrient fluxes are much higher, reaching values $>460 \mu \mathrm{mol} \mathrm{PO}_{4} \mathrm{~m}^{-2} \mathrm{~d}^{-1}$ and $>6600 \mu \mathrm{mol} \mathrm{NH}_{4} \mathrm{~m}^{-2} \mathrm{~d}^{-1}$ (Bonanni et al. 1992). Different studies have already shown that predicted diffusional flux rate cannot be compared with fluxes measured in benthic enclosures (Hines 1985, Johnstone et al. 1989). Dark (Johnstone et al. 1989) or light (Williams

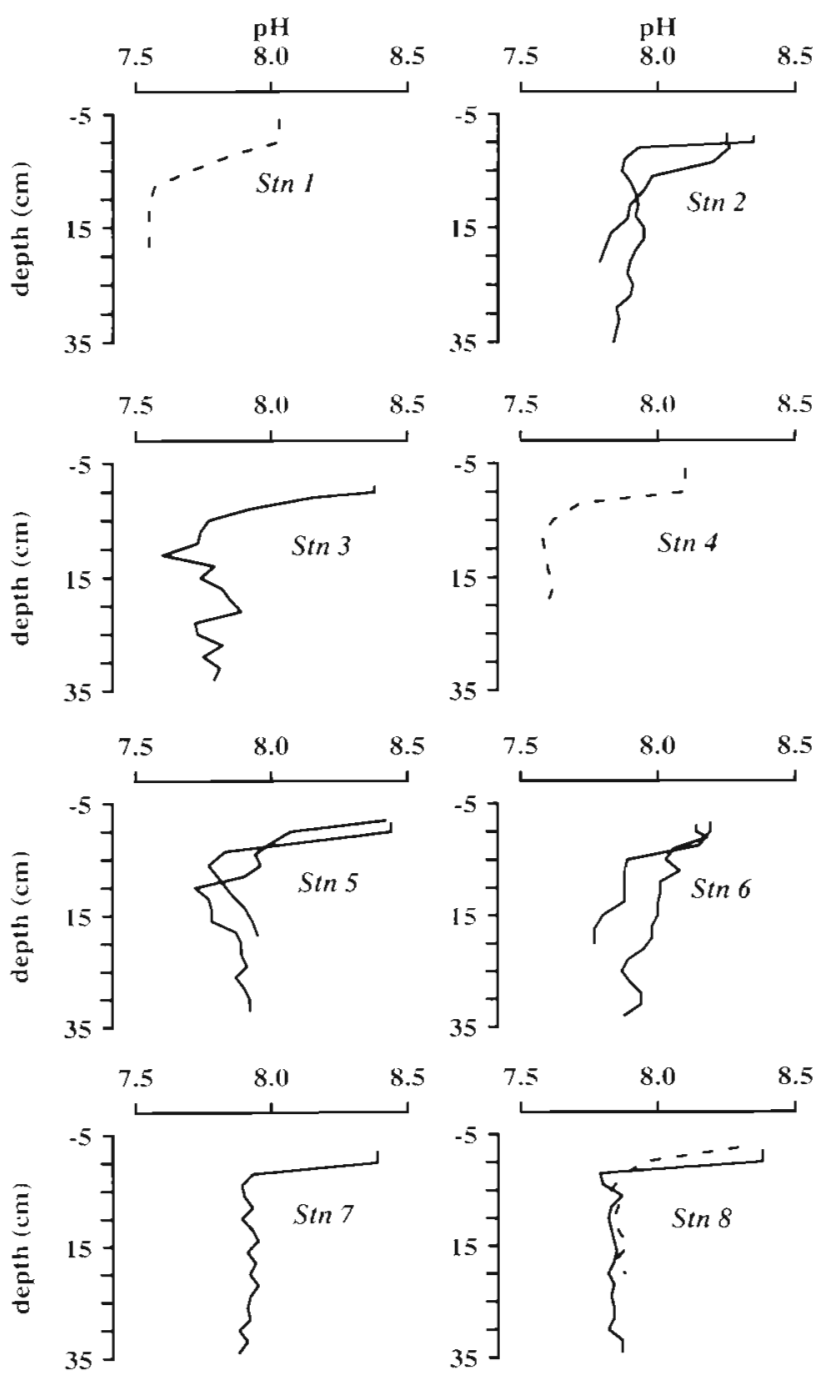

Fig. 7 Pore water profiles of pH. Dashed lines are 1987 data, solid lines are 1993 data

et al. 1985, Boucher \& Clavier 1990, Fisher et al. 1990) enclosure incubations can modify an active uptake process occurring in the top layers of the sediment (Sundbäck \& Graneli 1988).

\section{Nutrient budget of the water column}

In spite of the large range of the flux results, we will. try to compare them with other lagoonal $\mathrm{N}$ and $\mathrm{P}$ fluxes. $\mathrm{N}$ and $\mathrm{P}$ deposition rates (in term of particulate organic nitrogen and total phosphorus) were measured at Stn 6 (close to Stn 4) between 1986 and 1987 (Charpy \& Charpy-Roubaud 1991). The results were in the ranges: 904 to $8109 \mu \mathrm{mol} \mathrm{N} \mathrm{m}^{-2} \mathrm{~d}^{-1}$ (2575 \pm $\left.2494 \mu \mathrm{mol} \mathrm{N} \mathrm{m}{ }^{-2} \mathrm{~d}^{-1}\right)$ and 16 to $255 \mu \mathrm{mol} \mathrm{P} \mathrm{m} \mathrm{m}^{-2} \mathrm{~d}^{-1}(104$ $\left.\pm 81 \mu \mathrm{mol} \mathrm{P} \mathrm{m}{ }^{-2} \mathrm{~d}^{-1}\right)$. Therefore, average $\mathrm{N}(163 \mu \mathrm{mol}$ $\left.\mathrm{N} \mathrm{m}^{-2} \mathrm{~d}^{-1}\right)$ and $\mathrm{P}\left(4.5 \mu \mathrm{mol} \mathrm{P} \mathrm{m}^{-2} \mathrm{~d}^{-1}\right)$ fluxes from sedi- 

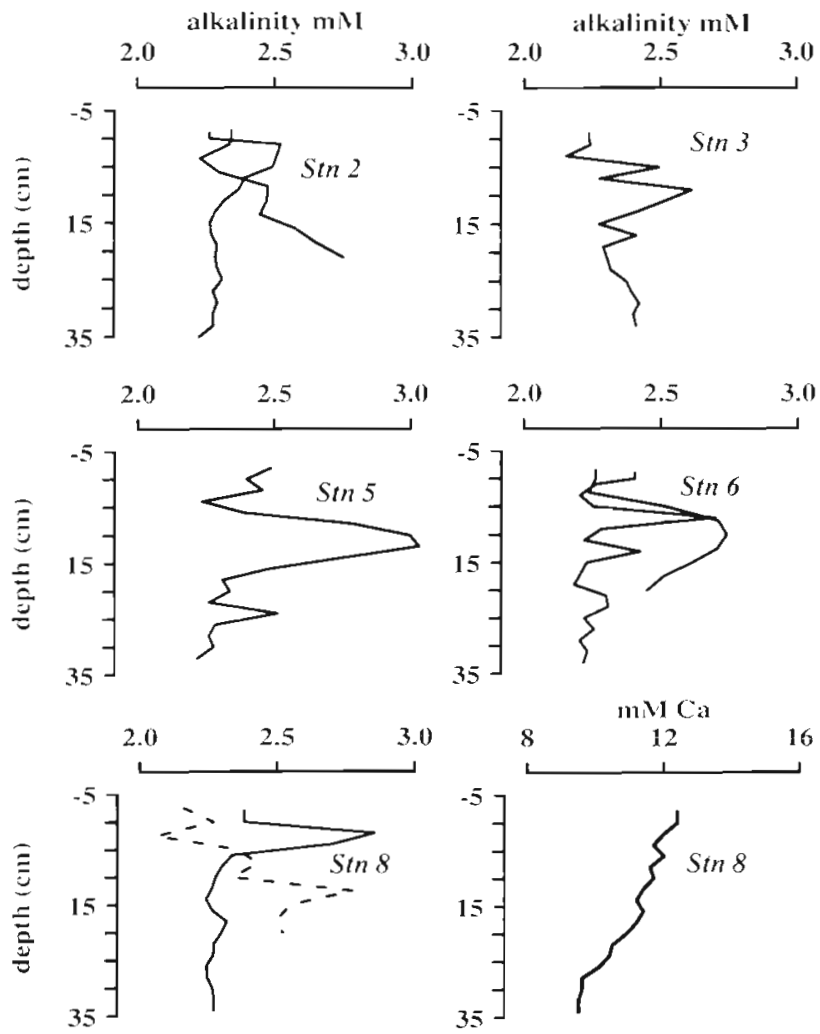

Fig. 8. Pore water profiles of alkalinity (mM; Stns $2,3,5,6,8$ ) and Ca concentrations (mM: Stn 8). Dashed lines are 1987 data, solid lines are 1993 data. No data for Stns 1, 4 and 7

ment represented respectively 6 and $4 \%$ of the average $\mathrm{N}$ and $\mathrm{P}$ deposition rates

The average atomic N:P ratio of the efflux at the SWI was 29:1, a value very close to the PON:POP (27:1) ratio in trapped material (Charpy \& Charpy-Roubaud 1991). Therefore, there was no sink or loss for regenerated $\mathrm{N}$ or $\mathrm{P}$ in sediments. However, the deepest stations ( 7 and 8 ) presented high N:P ratios (32 and 68). This implied that there was a sink for regenerated $N$ at these stations. Dollar et al. (1991) observed a similar feature in Tomales Bay (California).

Charpy \& Charpy-Roubaud (1990) demonstrated that total primary production (benthos + plankton) is independent of station depth and depends only on the light energy reaching the surface. Therefore, we can compare the fluxes at the WSI, which represent potential nutrient fluxes available for lagoonal primary producers, with mineral $N$ and $P$ requirements for this production. Average $\mathrm{P}_{-} \mathrm{PO}_{4}$ requirement for phytoplankton and phytobenthos is $603 \mu \mathrm{mol} \mathrm{P} \mathrm{m}^{-2} \mathrm{~d}^{-1}$ (Charpy \& Charpy-Roubaud 1989). N requirement may be estimated to $8849 \mu \mathrm{mol} \mathrm{m} \mathrm{m}^{-2} \mathrm{~d}^{-1}$ using an average uptake of carbon of $58,329 \mu \mathrm{mol} \mathrm{C} \mathrm{m} \mathrm{C}^{-2} \mathrm{~d}^{-1}$ (CharpyRoubaud et al, 1989) and a Redfield C:N ratio (6.6). Therefore, the flux of ammonium from the sediment
Table 2. Reported rates of diffusive nutrient fluxes from coral reef sediment

\begin{tabular}{|c|c|c|}
\hline Site & Flux $\left(\mu m o I m^{-2} \mathrm{~d}^{-1}\right)$ & Source \\
\hline \multicolumn{3}{|c|}{ Bermuda (shallow water) } \\
\hline $\mathrm{PO}_{4}$ & $0.5-7$ & \multirow[t]{2}{*}{ Hines (1985) } \\
\hline $\mathrm{NH}_{4}$ & $115-312$ & \\
\hline \multicolumn{3}{|c|}{ Puerto Rico (Mona Island) } \\
\hline $\mathrm{NH}_{4}$ & $16.8-23$ & Corredor \& Morrell (1985) \\
\hline \multicolumn{3}{|c|}{ Great Barrier Reef } \\
\hline $\mathrm{NH}_{4}$ & $44.4-61.2$ & Johnstone et al. (1989) \\
\hline $\mathrm{NH}_{4}$ & $10-94$ & Capone et al. (1992) \\
\hline \multicolumn{3}{|c|}{ St. Croix (Virgin Island) } \\
\hline $\mathrm{NH}_{4}$ & 9.4 & Fisher et al. (1990) \\
\hline \multicolumn{3}{|c|}{ South Sulawesi } \\
\hline $\mathrm{NH}_{4}$ & $104-306$ & Erftemeijer \& \\
\hline $\mathrm{PO}_{4}$ & $38-12.6$ & Middelburg (1993) \\
\hline \multicolumn{3}{|l|}{ Tikehau } \\
\hline $\mathrm{NH}_{4}$ & $4.4-387.0$ & This study \\
\hline $\mathrm{PO}_{4}$ & $0.9-12.0$ & \\
\hline $\mathrm{Si}$ & $2.3-68.3$ & \\
\hline
\end{tabular}

represents between 0.1 and $6.8 \%$ of the $\mathrm{N}$ requirement and the flux of phosphate between 0.1 and $1.7 \%$ of the $P$ requirement. Part of the $\mathrm{N}$ and $\mathrm{P}$ requirements must then be supplied by zooplanktonic excretion; for the micro + mesozooplankton in Tikehau, Le Borgne et al. (1989) estimated this contribution to be respectively 32 and $18 \%$ of phytoplankton $\mathrm{N}$ and $\mathrm{P}$ requirements, i.e. respectively 18 and $10 \%$ of phytoplankton + phytobenthos $N$ and $P$ requirements. The remainder can be supplied by other excretions, mineralization in the water column and $\mathrm{N}$ fixation.

\section{Mineralization of the organic matter}

All of the pore water concentration profiles show, whatever the location of the station, a global pattern which gives useful information about the bacteriamediated reactions which lead to the transformation of the sedimented or benthic organic material into mineral end-products. As a sufficient chemical data set was available only at $\mathrm{Stn} 8\left(\mathrm{H}_{2} \mathrm{~S}, \mathrm{SO}_{4}\right.$ and $\left.\mathrm{Ca}\right)$, the results obtained for this station will be investigated in detail. From these general trends we can infer the main geochemical processes which explain these observations.

At the very top of the sedimentary column (a few mm below the interface) dissolved oxygen may diffuse from the water column and oxidize part of the organic matter (OM) according to the reaction.

$$
\mathrm{CH}_{2} \mathrm{O}+\mathrm{O}_{2} \Rightarrow \mathrm{CO}_{2}+\mathrm{H}_{2} \mathrm{O}
$$


probably through an aerobic bacteria-mediated mechanism.

This reaction increases total dissolved $\mathrm{CO}_{2}$ but does not affect alkalinity appreciably; therefore, the $\mathrm{pH}$ must decrease owing to the input of the dissolved $\mathrm{CO}_{2}$ into the solution. But this $\mathrm{pH}$ variation would be moderated by the strong buffer effect of calcium carbonate dissolution.

With the oxygen concentration in the overlying sea water being $187 \mu \mathrm{M}$ (at $100 \%$ saturation with $\mathrm{S}=$ 35 PSU and $\mathrm{T}=301 \mathrm{~K}$ ) and the whole set of reactions being Reaction (1) and

$$
\mathrm{CaCO}_{3}+\mathrm{CO}_{2}+\mathrm{H}_{2} \mathrm{O} \leftrightarrow \mathrm{Ca}^{2+}+2 \mathrm{HCO}_{3}^{-}
$$

and supposing that the dissolved $\mathrm{CO}_{2}$ released in Reaction ( 1 ) is completely neutralized by the calcium carbonate in Reaction (2), then the maximum increase of the dissolved Ca will be $187 \mu \mathrm{M}$, which represents $1.5 \%$ of the total dissolved calcium. This variation is within the error range of the calcium analysis and cannot be detected on the calcium profile.

The consequence of the coupling of Reactions (1) and $(2)$ is an increase in alkalinity which is equal to twice the variation of total dissolved $\mathrm{Ca}$. We have shown that this is not detectable on the Ca profile; but, the set of reactions also shows that, if the dissolved $\mathrm{CO}_{2}$ is completely consumed by Reaction (2), the increase in alkalinity will also be equal to twice the oxygen depletion. Therefore, within the top $1 \mathrm{~cm}$ of the sediment, the alkalinity value would shift from 2.382 to $2.756 \mathrm{mM}$. As the observed value (deduced from the polynomial fit of the experimental profile) is $2.720 \mathrm{mM}$, the deviation from the calculated value is $1.3 \%$. Consequently, the hypothesis that Reactions (1) and (2) are the main geochemical processes at the top of the sediment is consistent with the measurements.

From $1 \mathrm{~cm}$ below the SWI and lower, the environment is completely anoxic, and soluble sulfide species $\left(\mathrm{H}_{2} \mathrm{~S}\right.$ and $\left.\mathrm{HS}^{-}\right)$appear in the pore water as a consequence of the anaerobic reduction of sulfate by the excess of OM which has not been oxidized by the oxygen.

At $\operatorname{Stn} 8$, the concentration of these species increased continuously with depth, but at Stn 5 the $\mathrm{H}_{2} \mathrm{~S}$ profile did not show a regular variation. This random evolution is mainly due to a nearly permanent bioturbation. For example, at Stn 2 the top of the sedimentary column was completely mixed and the composition of the pore water did not change within the top $3 \mathrm{~cm}$ below the SWI. The occurrence of burrows due to benthic activity provides many paths which allow oxygenated sea water to irrigate the sediment. In this very common case, the pore water has a highly variable composition which results from incomplete mixing between oxygenated and anoxic microenvironments
The oxidation of OM by sulfate can be, in a first approximation, written as

$$
\mathrm{CH}_{2} \mathrm{O}+1 / 2 \mathrm{SO}_{4}{ }^{2-}+\mathrm{H}^{+} \rightarrow 1 / 2 \mathrm{H}_{2} \mathrm{~S}+\mathrm{CO}_{2}+\mathrm{H}_{2} \mathrm{O}
$$

This simplification shows that the alkalinity increases (by $\mathrm{H}^{+}$consumption) to the same extent as the total dissolved $\mathrm{CO}_{2}$. However, we will later show that, when species other than organic $\mathrm{C}\left({ }^{\prime} \mathrm{CH}_{2} \mathrm{O}\right.$ ') are considered in the mineralization reaction (especially $\mathrm{N}$ linked to proteins and amino-acids), the alkalinity increases a little more than the total dissolved inorganic C (DIC). Therefore, the net effect of this reaction is to slightly increase $\mathrm{pH}$. This $\mathrm{pH}$ variation is moderated yet again by the calcium carbonate buffer effect. With rising $\mathrm{pH}$, a part of the DIC is converted into $\mathrm{CO}_{3}{ }^{2-}$ ions which, in turn, leads to precipitation of calcium carbonate.

Obviously, the sulfate profile should show a decreasing pattern as $\mathrm{H}_{2} \mathrm{~S}$ is released into the pore water. This pattern has been observed in many eutrophic coastal marine environments (Berner 1964, Gaillard et al. 1989) In this study, at $\mathrm{Stn} 8$, the maximum $\mathrm{H}_{2} \mathrm{~S}$ concentration reached $116 \mu \mathrm{M}$. The highest observed concentration at Tikehau was $365 \mu \mathrm{M}$ (Stn $5,13 \mathrm{~cm}$ below the SWI; Fig 2), a value which represents only $1 \%$ of the available sulfate pool. This variation being below the analytical precision, no variation was recorded on the sulfate profile.

\section{Geochemical processes and stoichiometry of the OM}

A fundamental hypothesis of diagenetic models such as those used by Berner (1977) or Rabouille \& Gaillard (1990) is the existence of a steady state within the pore water composition. A very active bioturbation is not compatible with this hypothesis; but, having identified the main geochemical processes, it is possible to quantify the amount of OM mineralized at Stn 8 through the observed concentration profiles and a simple stoichiometric model.

Reactions (1) and (3) can be rewritten more accurately by taking into account the contributions of $\mathrm{N}$ and $P$ : in the oxygenated $1 \mathrm{~cm}$ top layer

$$
\begin{aligned}
\left(\mathrm{CH}_{2} \mathrm{O}\right)_{x}\left(\mathrm{NH}_{3}\right)_{y} \mathrm{H}_{3} \mathrm{PO}_{4}+x \mathrm{O}_{2} \\
\rightarrow x \mathrm{CO}_{2}+y \mathrm{NH}_{3}+\mathrm{H}_{3} \mathrm{PO}_{4}+x \mathrm{H}_{2} \mathrm{O}
\end{aligned}
$$

and below the oxygenated top layer

$$
\begin{aligned}
\left(\mathrm{CH}_{2} \mathrm{O}\right)_{x}\left(\mathrm{NH}_{3}\right)_{y} \mathrm{H}_{3} \mathrm{PO}_{4}+x / 2 \mathrm{SO}_{4}{ }^{2-}+x \mathrm{H}^{+} \\
\rightarrow x / 2 \mathrm{H}_{2} \mathrm{~S}+x \mathrm{CO}_{2}+y \mathrm{NH}_{3}+x \mathrm{H}_{2} \mathrm{O}+\mathrm{H}_{3} \mathrm{PO}_{4}
\end{aligned}
$$

For the whole profile

$$
\mathrm{CaCO}_{3}+\mathrm{CO}_{2}+\mathrm{H}_{2} \mathrm{O} \leftrightarrow \mathrm{Ca}^{2+}+2 \mathrm{HCO}_{3}^{-}
$$

Within the oxygenated layer, for the total dissolved $\mathrm{CO}_{2}$

$$
\Delta \Sigma \mathrm{CO}_{2}=\Delta \mathrm{O}_{2}+\Delta \mathrm{Ca}
$$


and for the alkalinity

$$
\Delta \mathrm{Alk}=\frac{1-y}{x} \Delta \mathrm{O}_{2}+2 \Delta \mathrm{Ca}
$$

In Eq. (7), the borate contribution is assumed to be constant and the contribution of $\mathrm{H}_{3} \mathrm{SiO}_{4}^{-}$is neglected.

Below the oxygenated layer the variations of $\mathrm{\Sigma CO}_{2}$ and alkalinity become

$$
\text { and } \quad \Delta \mathrm{Alk}=\frac{2(x+y-1)}{x} \Delta \mathrm{H}_{2} \mathrm{~S}+2 \Delta \mathrm{Ca}
$$$$
\Delta \sum \mathrm{CO}_{2}=2 \Delta \mathrm{H}_{2} \mathrm{~S}+\Delta \mathrm{Ca}
$$

In order to improve the calculation of $\triangle \mathrm{Alk}$, the profile of $\mathrm{H}_{2} \mathrm{~S}$ is fitted with a polynomial function. This makes it possible to obtain a good estimate of $\Delta \mathrm{H}_{2} \mathrm{~S}$ for each depth increment $\Delta z$.

For the top centimeter, $\Delta \mathrm{O}_{2}$ is calculated by arbitrarily assuming an exponential decrease in the dissolved oxygen in order to get a negligible amount of $\mathrm{O}_{2}$ at $1 \mathrm{~cm}$ depth. Because the variation of $\mathrm{Ca}$ concentration is too small to be recorded on the experimental profile, $\triangle \mathrm{Ca}$ is set to 0

As $\sum \mathrm{CO}_{2}$ is calculated with the experimental values of alkalinity and $\mathrm{pH}$, this parameter is not independent from the alkalinity; therefore, the stoichiometric modeling will be applied only to generate a theoretical alkalinity profile which will be compared to the observed profile in order to test the validity of the assumptions

The calculation starts with the initial experimental data which represent the sea water composition a few centimeters above the interface. The experimental alkalinity profile is presented in Fig. 9 for Stn 8 along with the calculated one. The agreement between observed and calculated values is fairly good when the $\mathrm{C}: \mathrm{N}$ ratio $x / y$ is set to 9.6. If this ratio is set to the accepted value given by Redfield et al. (1963) for living marine phytoplankton, i.e. $\mathrm{C}: \mathrm{N}=6.6$, then an important shift is observed between the experimental data

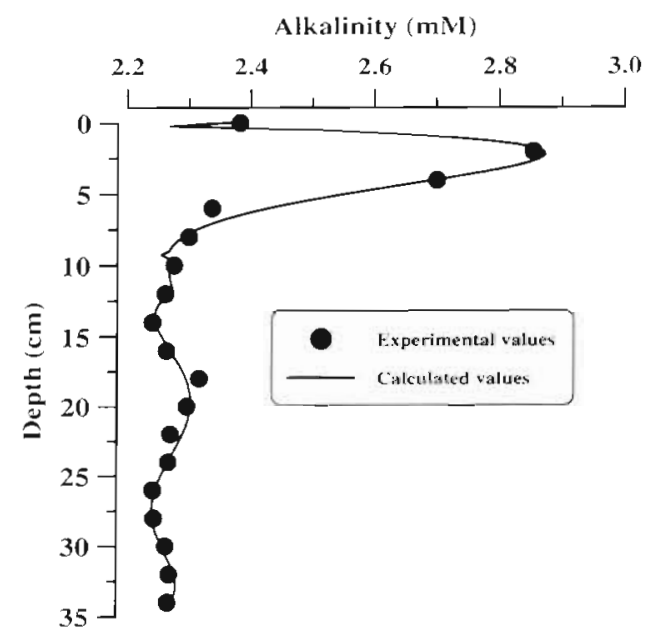

Fig. 9. Experimental and calculated alkalinity at Stn 8 in 1993 and the calculated profile especially in the range of 10 to $35 \mathrm{~cm}$ below the SWI. This result could be the consequence of 2 different processes: (1) The OM which reaches the sediment has a major component represented by the phytoplankton which has already undergone oxidation by dissolved oxygen within the water column during the sedimentation process. As organicrich nitrogen compounds (proteins, amino-acids and amino-sugars) are more labile than carbohydrates, then the OM transformed within the sediment is depleted in $\mathrm{N}$ and its stoichiometric formula should be $\left(\mathrm{CH}_{2} \mathrm{O}\right)_{106}\left(\mathrm{NH}_{3}\right)_{11}\left(\mathrm{H}_{3} \mathrm{PO}_{4}\right)$ which corresponds to $\mathrm{C}: \mathrm{N}=$ 9.6. (2) The OM oxidized within the sediment is a mixture containing phytoplankton and another type of $O M$ with a lower $\mathrm{C}: \mathrm{N}$ ratio, which could be a contribution of dead benthic material.

\section{Quantitative estimation of the diagenetic reactions}

We can estimate the amount of OM mineralized by the 2 main oxidation reactions from Eqs. (4) and (5).

In the upper centimeter, the stoichiometry of the reaction yields $\triangle 0 \mathrm{M} / \Delta \mathrm{O}_{2}=1 / x$. If $x=106$ and $\mathrm{O}_{2}=187 \mu \mathrm{M}$, then $\mathrm{OM}=1.8 \mu \mathrm{M}$. In the top centimeter of the sediment the porosity ( $\phi)$ was 0.62 . Assuming a density of $2.5 \mathrm{~g} \mathrm{~cm}^{-3}$ for coral sand and $1.025 \mathrm{~g} \mathrm{~cm}^{-3}$ for sea water, then we find that $2.5 \mathrm{mg}$ of $\mathrm{OM}$ is oxidized per $\mathrm{kg}$ of total sediment (solid + pore water).

Below and down to $34 \mathrm{~cm}$ below the interface the stoichiometry of the reaction yields $\triangle O M / \Delta H_{2} \mathrm{~S}=2 / x$. If $x=$ 106 and $\mathrm{H}_{2} \mathrm{~S}=116 \mu \mathrm{M}$, then $\mathrm{OM}=2.2 \mu \mathrm{M}$. With an average $\phi$ of 0.57 (between 1 and $34 \mathrm{~cm}$ below the interface) the same calculation gives $2.7 \mathrm{mg}$ of OM per $\mathrm{kg}$ of total sediment.

For the whole sediment the extent of the mineralization processes is restricted to $5.2 \mathrm{mg}$ of organic material per $\mathrm{kg}$ of sediment $(5.2 \mathrm{ppm})$. This value seems very low compared to the results obtained by Gaillard et al (1989) for marine sediment of the Mediterranean coast, where the organic carbon content of the mud is around $3 \%$. Our result emphasizes the oligotrophic status of the global lagoonal ecosystem.

\section{Chemical equilibrium between the aragonitic coral sand sediment and the pore water}

To determine if the coupled reaction of dissolution/ precipitation of the calcium carbonate occurs within equilibrium conditions, a saturation index $(S I)$ was calculated with respect to the most probable carbonate phase, the aragonite, and alternatively for calcite.

$S I$ is defined as

$$
S I=\frac{[\mathrm{Ca}]\left[\mathrm{CO}_{3}\right]}{K_{\mathrm{s}}}
$$


The expressions between brackets refer to total concentrations. [Ca] and $\left[\mathrm{CO}_{3}\right]$ represent the total dissolved calcium and carbonate respectively as well as free ions and complexed forms (e.g. $\mathrm{CaCO}_{3}{ }^{\circ}, \mathrm{CaSO}_{4}{ }^{0}$, $\mathrm{NaCO}_{3}{ }^{-}$and other complexes containing carbonate and calcium species). The values of the stoichiometric constant of solubility $K_{3}$ (Mucci 1983) are $6.34 \times 10^{-7}$ and $4.23 \times 10^{-7}$ for aragonite and calcite respectively, at $\mathrm{T}=301 \mathrm{~K}$ and $\mathrm{S}=35 \mathrm{PSU}$.

[Ca] is the analytical concentration of dissolved calcium but $\left[\mathrm{CO}_{3}\right]$ must be calculated from the values of carbonate alkalinity and $\mathrm{pH}$. The carbonate alkalinity is given by the expression $\mathrm{Alk}_{\mathrm{c}}=\left[\mathrm{HCO}_{3}\right]+2\left[\mathrm{CO}_{3}\right]$ which is the total alkalinity minus the borate contribution. Correction for borate alkalinity is made using the relation given by Uppström (1974) for Pacific sea water: $B_{\mathrm{t}}=C l \times 0.02146$ where $B_{1}$ is the total boron concentration in mol $\mathrm{kg}^{-1}(\mathrm{M})$ and $C l$ is the chlorinity

Then

$$
\left[\mathrm{CO}_{3}\right]=\frac{\mathrm{Alk}_{\mathrm{C}}}{2+1 \mathrm{U}^{\left(\mathrm{p}^{k_{2}}-\mathrm{pH}\right)}}
$$

where $\mathrm{p} K_{2}$ is the second dissociation constant of $\mathrm{H}_{2} \mathrm{CO}_{3}$ calculated on the ionic medium scale (Almgren et al. 1975) while the $\mathrm{pH}$ values are measured on the same scale defined by Hansson (1973) at $\mathrm{T}=301 \mathrm{~K}$ and $\mathrm{S}=$ 35 PSU.

With an SI value very close to 1 , an equilibrium between the pore water and the sediment can be inferred. With $S I \gg 1$, the solution is supersaturated with respect to a solid phase which can precipitate. The opposite situation, when $S I<1$, reflects an undersaturation where the solid phase considered can dissolve.

Fig. 10 shows that the whole pore water profile is supersaturated with respect to both carbonates. The highest supersaturation occurs within the upper cen-

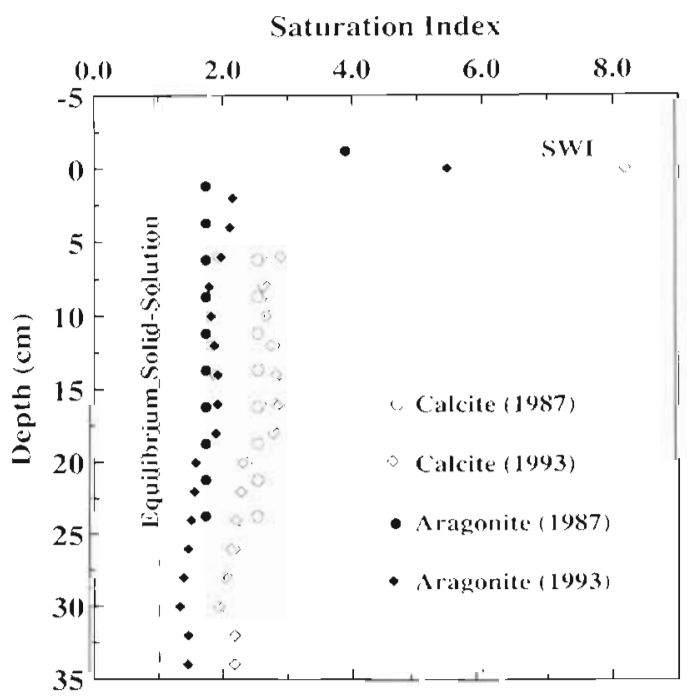

Fig. 10. Profiles of saturation index (SI) for Calcite and Aragonite at $\operatorname{Stn} 8$ timeter $(S I=5.5$ and 8.2 for aragonite and calcite respectively at the SWI). This confirms the hypothesis that the oxidation of OM by dissolved oxygen leads to the dissolution of coral sand, although this dissolution does not appear on the calcium profile. Below the upper centimeter, supersaturation decreases, but SI remains close to 2 for aragonite. Then, when oxidation of the OM is controlled by sulfate, the carbonate phase precipitates and inhibits any $\mathrm{pH}$ increase.

\section{SUMMARY AND CONCLUSIONS}

The sediments of Tikehau lagoon are sources of $\mathrm{N}(4$ to $\left.601 \mu \mathrm{mol} \mathrm{NH}_{4} \mathrm{~m}^{-2} \mathrm{~d}^{-1}\right), \mathrm{P}\left(0.6\right.$ to $10.3 \mu \mathrm{mol} \mathrm{PO}_{4} \mathrm{~m}^{-2}$ $\mathrm{d}^{-1}$ ) and dissolved silica ( 3 to $79 \mu \mathrm{mol} \mathrm{SiO}_{2} \mathrm{~m}^{-2} \mathrm{~d}^{-1}$ ) to the overlying water column. $N$ and $P$ effluxes from sediments represented 6 and $4 \%$ of $\mathrm{N}$ and $\mathrm{P}$ deposition rates respectively. As a general trend, there was no sink of regenerated $\mathrm{N}$ and $\mathrm{P}$. $\mathrm{N}$ and $\mathrm{P}$ fluxes represent between 0.1 and $6.8 \%$ of the $\mathrm{N}$ requirement and between 0.1 and $6.8 \%$ of the $P$ requirement of lagoonal primary production. A great part of the OM which reaches the sediment is oxidized in the water column. The $O M$ oxidized within the sediment is a mixture of sedimented and benthic material. The amount of OM mineralized within the sediment is $2.5 \mathrm{mg} \mathrm{kg}^{-1}$ in the upper centimeter and $5.2 \mathrm{mg} \mathrm{kg}^{-1}$ in the lower centimeters. Sediment pore water is supersaturated with respect to aragonite and calcite. This fact has already been observed by many workers: Morse et al. (1985), Sayles (1985), Gaillard et al. (1989) The persistence of the supersaturation shows that the kinetics of the carbonate dissolution are faster than the reverse reaction. An hypothesis to explain this persistence is the presence of phosphates or organic compounds poisoning the surfaces of the crystals and inhibiting nucleation (Berner et al. 1978). One interesting aspect of this analysis of the data is that it shows that the dissolutionprecipitation of a carbonate - which, obviously, here is aragonite - plays an important role in pore water composition even though this reaction cannot be detected on the calcium profile

Acknowledgements. We thank J.-L. Cremoux, P. Ebner, N Maihota for help in field analysis and diving and A. W. D Larkum for critical review of the manuscript.

\section{LITERATURE CITED}

Almgren T, Dyrssen D, Strandberg M (1975) Determination of $\mathrm{pH}$ on the moles per $\mathrm{kg}$ seawater scale $\left(\mathrm{M}_{\mathrm{w}}\right)$. Deep Sea Res 22:635-646

Atkinson MJ (1989) Are coral reefs nutrient-limited? In: Choat JH et al. (eds) Proc 6th int Coral Reef Symp 1:157-166 Berner RA (1964) An idealized model of dissolved sulfate dis- 
tribution in recent sediments. Geochim Cosmochim Acta 28:1497-1503

Berner RA (1977) Stoichiometric models for nutrient regeneration. Limnol Oceanogr 29:781-786

Berner RA, Westrich JT, Graber R, Smith RJ, Martens CS (1978) Inhibition of aragonite precipitation from supersaturated seawater: a laboratory and field study. Am J Sci 278:816-837

Bonanni P, Caprioli R, Ghiara $E_{i}$ Mignuz:ri R, Orlandi C, Paganin G, Monti A (1992) Sediment and interstitial water chemustry of the Orbetello lagoon (Grosseto, Italy); nutrient diffusion across the water-sediment interface. Hydrobiologia 235/236:553-568

Boucher G, Clavier J (1990) Contribution of benthic biomass to overall metabolism in New Caledonia lagoon sediments. Mar Ecol Prog Ser 64:271-280

Capone DG, Dunham SE, Horrigan SG, Duguay LE (1992) Microbial nitrogen transformations in unconsolidated coral reef sediments. Mar Ecol Prog Ser 80:75-88

Charpy L, Charpy-Roubaud CJ (1989) Phosphorus budget in an atoll lagoon. In: Choat $\mathrm{JH}$ et al. (eds) Proc 6th int Coral Reef Symp 2:547-550

Chaipy L, Charpy-Roubaud CJ (1990) A model of light-primary production relationship in an atoll lagoon (Tikehau, Tuamotu Archipelago, French Polynesia). J mar biol Ass UK $70: 357-369$

Charpy L, Charpy-Roubaud CJ (1991) Particulate organic matter fluxes in a Tuamotu atoll lagoon (French Polynesia). Mar Ecol Prog Ser 71:53-63

Charpy-Roubaud CJ, Charpy L, Cremoux JL (1990) Nutrient budget of the lagoonal waters in an open central South Pacific atoll (Tikehau, Tuamotu, French Polynesia). Mar Biol 107:67-73

Charpy-Roubaud CJ, Charpy L, Lemasson L (1989) Benthic and planktonic primary production of an open atoll lagoon (Tikehau, French Polynesia). In: Choat JH. et ai. (eds) Proc 6th int Coral Reef Symp 2:551-556

Corredor JE, Morell J (1985) Inorganic nitrogen in coral reef sediments. Mar Chem 16:379--384

Crossland CJ (1983) Dissolved nutrients in coral reef waters. In: Barnes DJ (ed) Perspectives on coral reefs. AIMS 200, Townsville, p 276

Devol AH, Ahmed IT (1981) Are the high rates of sulphate reduction associated with anaerobic oxidation of methane? Nature 291:407-408

Dollar SJ, Smith SV, Vink SM, Obrebski S, Hollibaugh JT (1991) Annual cycle of benthic nutrient fluxes in Tomales Bay, California, and contribution of the benthos to total ecosystem metabolism. Mar Ecol Prog Ser 79:115-125

Erftemejjer PLA, Middelburg JJ (1993) Sediment-nutrient interactions in tropical seagrass beds: a comparison between a terrigenous and a carbonate sedimentary environment in South Sulawesı (Indonesia). Mar Ecol Prog Ser 102:187-198

Fisher TR, Morrissey KN, Smith LK, Williams SL, Baptist G, Ward LG, Twilley R, D'Elia CF, Zimba PF (1990) Final Science Report of NURP Hydrolab Mission 85-1 NOAA, Washington, $\mathrm{DC}$

Gaıllard JF, Paunels H, Michard G (1989) Chemical diagenesis in coastal marine sediments. Oceanol Acta 12:175-187

Hansson L (1973) A new set of pH-scales and standard buffers for sea water. Deep Sea Res 20:479-491

Harmelin-Vivien M (1985) Atoll de Tikehau, Archipel des Tuamotu. Proc Sth int Coral Reefs Congr 1:211-268

Hatcher BG (1990) Coral reef primary productjvity: a hierarchy of pattern and process. TREE (Trends Ecol Evol)
$5: 149-155$

Hesslein RH (1976) An in situ sampler for close interval pore water studies. Limnol Oceanogr 21:912 -924

Hines ME (1985) Microbial biogeochemistry in shallow water sediments of Bermuda. Proc 5th int Coral Reets Congr 3: $427-432$

Intes A. Arnaudin H (1987) Esquisse sédimentologique du lagon de Tikehau. Notes Doc ORSTOM Tahitı Ser Oceanogr 35:71-100

Johnstone R, Koop K, Larkum AWD (1989) Fluxes of inorganic nitrogen between sediments and water in a coral reef lagoon. Proc Linn Soc NSW 110(3):219-227

Kinsey DW (1985) Metabolism, calcification, and carbon production. Proc 5th int Coral Reefs Congr 4:504-526

Le Borgne R., Blanchot J, Charpy L (1989) Zooplankton of the atoll of Tikehau (Tuamotu Archipelago) and its relationship to particulate matter. Mar Biol 102:341-353

Lenhardt X (1991) Hydrodynamique des lagons d'atolls et d'îles hautes en Polynésie Française. Editions de l'ORSTOM, Etudes et Thèses, Paris

Lewis JB (1977) Processes of organic production on coral reefs. Biol Rev 52:305-347

Li YH, Gregory S (1974) Diffusion of lons in sea water and in deep-sea sediment. Geochim Cosmochim Acta 33: $703-714$

Manheim FT (1970) The diffusion of ions in unconsolidated sediments. Earth Planet Sci Lett 33:1-10

Morse JW, Zullig JJ, Bernstein LD, Millero FJ, Milne P, Mucci A, Choppin GR (1985) Chemistry of calcium carbonaterich shallow water sediments in the Bahamas. A.m J Sci 285:147-185

Mucci A (1983) The solubility of calcite and aragonite in sea water at various salinities, temperatures and one atmosphere total pressure. Am J Sci 285:780-799

Rabouille C. Gaillard JF (1990) The validity of steady-state flux calculations in early diagenesis: a computer simulation of deep-sea silica diagenesis. Deep Sea Res 37 : $625-646$

Redfield AC, Ketchum BH, Richards FA (1963) The influence of organisms on the composition of sea water. In: Hill MN (ed) The sea, Vol II, Composition of sea-water. Comparative and descriptive oceanography. John Wiley \& Sons, New York, p 26-77

Rutgers van der Loeff MM, Anderson LG, Hall POJ, Iverfeldt A, Josefson AB, Sundby B, Westerlund SFG (1984) The asphyxiation technique. An approach to distinguish between molecular diffusion and biologically mediated transport at the sediment-water interface. Limnol Oceanogr 29:675-686

Sayles FL (1985) $\mathrm{CaCO}_{3}$ solubility in marine sediments: evidence for equilibrium and nonequilibrium behavior. Geochim Cosmochim Acta 49:877-888

Stumm W, Morgan JJ (1981) Aquatic chemistry. Wiley-Interscience, New York

Sundbäck K, Granéli W (1988) Influence of microphytobenthos on the nutrient flux between sediment and water: a laboratory study. Mar Ecol Prog Ser 43:63-69

Sweerts JPRA, Kelly CA, Rudd JWM, Hesslein R, Cappenberg TE (1.991) Similarity of whole-sediment molecular diffusion coefficients in freshwater sediments of low and high porosity. Limnol Oceanogr 36:335-342

Uppström L (1974) The boron/chlorinity ratio in deep-sea water from the Pacific Ocean. Deep Sea Res 21:161-163

Williams SL, Gill IP, Yarish SM (1985) Nitrogen cycling in backreef sediments (St. Croix, U.S. Vircin Islands). Proc 5th int Coral Reefs Congr 3:389-394 